\title{
Bahasa Reseptif Anak Usia 3-6 Tahun di Indonesia
}

\author{
Salma Aulia Khosibah ${ }^{1 凶}$, Dimyati ${ }^{2}$ \\ Pendidikan Anak Usia Dini, Universitas Negeri Yogyakarta \\ DOI: $\underline{10.31004 / o b s e s i . v 5 i 2.1015}$
}

\begin{abstract}
Abstrak
Pada saat anak memasuki usia pra sekolah atau 3-6 tahun, anak siap mengikuti kegiatan belajar di pendidikan anak usia dini. Kegiatan belajar di pendidikan anak usia dini tujuan memberikan fondasi bagi seluruh aspek perkembangan yang dimiliki anak, salah satunya yakni perkembangan bahasa. Perkembangan bahasa merupakan hal yang sangat dinantikan, seperti kemampuan baca tulis. Sebelum anak mampu memproduksi bahasa berupa baca tulis, anak perlu untuk mengembangkan kemampuan dalam bahasa reseptif. Bahasa reseptif adalah kemampuan untuk memahami kata dan bahasa yang melibatkan perolehan informasi dan makna. Bahasa reseptif pada anak usia 3-6 tahun menjadi dasar baginya untuk mengungkapkan emosi, pesan, bersosialisasi, dan belajar ketahap perkembangan berikutnya. Penelitian ini bertujuan untuk mengetahui bahasa reseptif pada anak usia 3-6 tahun di Indonesia. Penelitian ini berjenis kajian literatur. Menggunakan teknik analisis deskriptif dengan menggunakan data berdasarkan jurnal, buku, ebook, dan literatur yang berkaitan dengan bahasa reseptif pada anak usia 3-6 tahun di Indonesia.
\end{abstract}

Kata Kunci: kemampuan bahasa, bahasa reseptif, anak.

\begin{abstract}
When the child enters pre-school age or 3-6 years, the child is ready to participate in learning activities in early childhood education. Learning activities in early childhood education aim to provide a foundation for all aspects of a child's development, one of which is language development. Language development is something that is highly anticipated, such as literacy. Before children are able to produce language in the form of reading and writing, children need to develop skills in receptive language. Receptive language is the ability to understand words and language which involves acquiring information and meaning. Receptive language in children aged 3-6 years becomes the basis for him to express emotions, messages, socialize, and learn the next stage of development. This study aims to determine receptive language in children aged 3-6 years in Indonesia. This research is a literature review. Using descriptive analysis techniques using data based on journals, books, ebooks, and literature related to receptive language in children aged 3-6 years in Indonesia.
\end{abstract}

Keywords: language skill, receptive language, children.

Copyright (c) 2021 Salma Aulia Khosibah, Dimyati

$\square$ Corresponding author:

Email Address : salma824@gmail.com (Sleman, Yogyakarta)

Received 30 December 2020, Accepted 24 January 2021, Published 28 January 2021 


\section{PENDAHULUAN}

Manusia tumbuh dan berkembang di berbagai aspek yakni, perkembangan fisik (tubuh, otak, sensorik, dan keterampilan motoric), perkembangan social emosional, perkembangan kognitif atau intelegensi (belajar, mememori, menalar, berpikir, dan bahasa) (Papalia, 2015). Tumbuh dan kembang manusia berupa meningkatkan kuantitas dan kualitas individu. Salah satu aspek perkembangan tersebut yakni perkembangan bahasa. Bahasa merupakan hal penting di dalam kehidupan manusia sebagai alat yang digunakan manusia untuk berkomunikasi satu sama lain. Bahasa adalah alat komunikasi antaranggota masyarakat berupa simbol bunyi yang dihasilkan yang oleh alat ucap manusia (Arnianti, 2019: 140). Dengan adanya bahasa, manusia mampu mengungkapkan ide, pikiran, perasaan atau informasi kepada orang lain. Bahasa dipergunakan pada sebagian besar aktivitas manusia, berupa bahasa manusia tidak dapat mengungkapkan perasaanya, menyampaikan keinginan, memberikan saran dan pendapat, bahkan sampai tingkat pemikiran seseorang yang berkaitan dengan bahasa. Semakin tinggi tingkat penguasaan bahasa seseorang, semakin baik pula penggunaan bahasa dalam berkomunikasi dan memaksimalkan potensi yang ada dalam diri individu. Dengan penguasaan bahasa maka dapat memaksimalkan aspek perkembangan yang lain, seperti kognitif, linguistic, social emosional (McIntyre et al., 2017: 1).

Kebutuhan akan penggunaan bahasa tidak hanya diperlukan bagi aktivitas individu dewasa, namun bahasa digunakan juga bagi anak usia dini atau usia 0-6 tahun. Pada masa ini jutaan sel-sel otak anak memiliki perkembangan besar untuk mencapai dan mendapatkan informasi tentang aspek perkembangannya (Amer Hasan, Marilou Hyson, 2013: 20). Anak usia dini memiliki kemampuan pesat dalam belajar, biasa disebut sebagai pembelajar ulung atau golden age. Golden age atau masa keemas an ini menjadi fondasi dan tonggak bagi tumbuh dan kembang manusia yang dipengaruhi oleh pengalaman belajar (Rusniah, 2017: 116). Pada usia ini merupakan masa yang tepat bagi manusia untuk mempelajari bahasa karena perkembangan bahasa anak terjadi pada 5 tahun pertama saat perkembangan otaknya sangat pesat terjadi (McIntyre et al., 2017: 1). Para orang tua memberi perhatian lebih terhadap perkembangan bahasa awal seperti ketika anak sudah mampu merespon atau mengucapkan kata pertama. Pada anak usia dini, kemampuan bahasa memiliki tingkat kemudahan dalam menerima dan memahami terhadap pemerolehan pengetahuan yang baru dibandingkan dengan perkembangan logika, dikarenakan salah satu karakteristik anak adalah meniru sehingga ketika orang dewasa berbicara, anak akan mengamati bagaimana pelafalan dari kata-kata tersebut (Alam \& Lestari, 2019: 275). Anak usia dini memiliki paling banyak periode sensitif untuk memperoleh aspek tumbuh kembang dan mereka perlu dibantu dan dirangsang tumbuh dan kembangnya (Clarissa \& Zulfikar, 2018: 276). Rangsangan penting diberikan kepada anak-anak karena cara belajar anak yakni memahami, meniru, dan dengan sengaja menyebutkan semua yang ada di dalamnya sekitarnya menjadi kata-kata. Anak dapat melakukan kesalahan dalam pengembangan bahasa. Kesalahannya seperti pengucapan, urutan kata, struktur (Fitriani, S., 2019: 130). Pada saat memasuki usia sekolah perkembangan bahasa anak usia dini menjadi focus perkembangan bersama guru, dengan kisaran usia 3-6 tahun. Usia 3 tahun dianggap sebagai periode paling cepat pertumbuhan bahasa. Pada usia anak di pendidikan anak usia dini (PAUD) atau 3-6 tahun, perkembangan bahasa menjadi perkembangan yang sangat dinantikan seperti kemampuan anak dalam membaca dan menulis. Kedua hal tersebut merupakan kemampuan dalam berbahasa yang membutuhkan waktu yang cukup lama. Oleh karena itu, dalam proses penguasaan dan perkembangan bahasa, anak-anak membutuhkan bimbingan dan lingkungan yang baik sebagai salah satu faktor penting. Ini karena mereka adalah peniru bahasa yang hebat yang berbicara di sekitar mereka. Aktivitas anak dalam mengamati bahasa sangat intens dan perlunya pengalaman penginderaan pendengaran yang aktif. Pemerolehan dan pemahaman bahasa yang melalui indera pendengaran adalah bahasa reseptif. 
Bahasa reseptif adalah kemampuan untuk memahami kata dan bahasa melibatkan perolehan informasi dan makna dari aktifitas sehari-hari (misalnya kita telah menyelesaikan sarapan kita, selanjutnya saatnya berpakaian, informasi visual dalam lingkungan (misalnya ibu memegang kuncinya berarti kita akan naik mobil, lampu hijau berarti pergi), suara dan kata-kata (misalnya sirene artinya mobil pemadam kebakaran akan datang, kata bola berarti benda bulat yang melenting bermain dengan), konsep seperti ukuran, bentuk, warna dan waktu, tata bahasa (misalnya jamak biasa: cat / s, regular past tense: fetch / ed) dan informasi tertulis (mis. tanda-tanda di lingkungan seperti "tidak memanjat", cerita tertulis). Sehingga, bahasa reseptif diperoleh dari pengalaman belajar anak yang menghubungkan lambang bahasa yang diperolehnya melalui pendengaran dan pengamatan yang bertujuan untuk memahami mimic dan nada suara yang kemudian mengerti arti kata (Kid Sense Child Development, 2013). Kemampuan bahasa reseptif pada anak juga terdapat dalam Permendikbud No 137 Tahun 2014 dalam lampiran I mencantumkan beberapa poin lingkup perkembangan yaitu: (1) memahami beberapa perintah secara bersamaan; (2) mengulang kalimat yang lebih kompleks; (3) memahami aturan dalam suatu permainan; dan (4) senang dan menghargai bacaan (Permendikbud, 2014).

Kemampuan bahasa reseptif membuat anak dapat memahami kata-kata, kalimat, cerita dan peraturan. Sebagaimana fungsi bahasa yaitu sebagai alat untuk menyatakan perasaan dan buah pikiran kepada orang lain (Susanto, 2016). Bahasa reseptif menjadi sangat penting karena adanya pemahaman bahasa sehingga komunikasi berhasil. Anak usia dini emmahami bahasa menjadi dasar baginya untuk belajar kepada tahap perkembangan bahasa berikutnya seperti membaca dan menulis sebagai alat belajar serta beraktivitas. Kesulitan dalam bahasa reseptif ini dapat menyebabkan kesulitan perhatian dan mendengarkan bahkan masalah perilaku, seperti dalam kegiatan belajar dan beraktivitas karena anak belum mampu menanggapi pertanyaan dan permintaan dengan tepat. Penelitian Ersan $(2020 ; 4)$ menyimpulkan bahwa kemampuan bahasa reseptif anak meningkat maka tingkat agresi fisik dan relasinya akan menurun. Sebagian besar aktivitas memerlukan pemahaman bahasa yang baik, hal ini juga dapat mempersulit anak usia dini untuk mengakses kurikulum atau terlibat dalam kegiatan dan tugas akademis di pendidikan anak usia dini (PAUD). Dalam usaha meningkatkan kemampuan bahasa reseptif anak usia dini, perlu memiliki bimbingan dan aktifitas mendukung. Aktifitas mendukung perkembangan bahasa reseptif dapat dilakukan di lingkungan terdekat anak seperti rumah atau pendidikan anak usia dini (jika sudah bersekolah). Rumah atau keluarga di dalamnya memiliki peranan penting dalam meningkatankan bahasa reseptif. Dikarenakan salah satu karakteristik anak adalah meniru sehingga ketika orang dewasa berbicara, anak akan mengamati bagaimana pelafalannya (Alam \& Lestari, 2019: 275). Bahasa yang pertama kali didengar oleh anak adalah bahasa ibu dan aktivitas harian anak akan mengamati kebiasaan ibu.

Budaya literasi dini seperti di negara barat contohnya membacakan dongeng sebelum tidur, berbagi cerita bersama, story telling merupakan kegiatan yang sangat baik untuk kebutuhan peningkatan bahasa reseptif anak (Nichola\&Indy, 2010:15). Berbeda dengan di Indonesia, kegiatan seperti membacakan dongeng, berbagi cerita, dan story telling cenderung hanya dilakukan pada saat anak usia dini berada di sekolah. Sedangkan, aktifitas di sekolah sangat terbatas dan keintiman yang minim karena ratio anak didik dan guru yang terbatas. Penelitian mengenai perkembangan anak di Indonesia oleh Lim (2013: 6), membuktikan bahwa pengalaman seperti membaca buku, bercerita, atau mencoret-coret kertas menjadi aktivitas yang jarang dilakukan anak usia 4 tahun Indonesia di rumah dengan prosentase $17 \%$ saja. Reseptif anak usia dini di Indonesia juga terkait dengan pemerolehan bahasa dari fonologi, yakni anak usia dini di Indonesia membutuhkan waktu yang lama dalam karena bahasa Indonesia kebanyakan katanya polisilabik (Chairunnisa, 2018: 129). Hal tersebut menyebabkan anak perlu untuk menganalisis kata terlebih dahulu baru menentukan suku mana yang akan diambil. Prosentase literasi dan kecenderungan sulitnya pemerolehan bahasa Indonesia pada anak usia dini menjadi salah satu dorongan agar dalam pengguasaan bahasa 
pada anak usia dini perlu diberikan lebih maksimal, dengan lebih mengoptimalakan faktor stimulus bahasa reseptif pada anak usia dini. Faktor-faktor inilah yang kemudian menjadi jembatan agar perkembangan bahasa, khususnya bahasa reseptif pada anak usia pra sekolah atau usia 3-6 tahun.

\section{METODOLOGI}

Metode penelitian ini yakni menggunakan kajian literatur. Kajian literatur merupakan metode penelitian yang mengkaji secara klinis gagasan, penegtahuan, atau temuan yang didapatkan melalui literatur, merumuskan kontribusi secara teoritis dan metodologi untuk topik tertentu (Woodrow \& Woodrow, 2019: 119). Kajian literatur melakukan evaluasi dari berbagai sumber atau temuan ilmiah. Sumber yang digunakan dalam kajian literatur ini dari berbagai sumber yang berhubungan dengan topik terkait dari, jurnal, paper dari conference, thesis, disertasi, buku, e book, dan pustaka lain yang relevan.

Kajian pustaka bertujuan untuk menginformasikan hasil-hasil penelitian yang berkaitan, menghubungkan penelitian dengan literatur yang ada, serta mengisi kekurangan yang terdapat dalam penelitian (Creswell, 2007). Tujuan penelitian ini yakni untuk mengetahui melalui analias kajian pustaka mengenai bahasa reseptif anak usia dini khususnya di Indonesia. Kajian literatur yang digunakan dalam penelitian ini bersifat analisiss deskriptif. Analisis deskripti dengan menjabarkan secara teratur melalui data yang diperoleh. Analisis diberikan untuk mempermudah pembaca dalam memahami tentang suatu topik dengan kekuatan berbagai penelitian (Rhoades, 2011: 61). Dengan mengkaji temuan penelitian sebelumnya atau state of art, dapat memberikan hipotesis sekaligus pembenaran penelitian yang dilakukan.

State of Art penelitian ini diambil dari beberapa contoh penelitian terdahulu sebagai panduan mengenai kemampuan bahasa reseptif anak usia dini. Berdasarkan jurnal-jurnal terdahulu yakni penelitian Media Belajar Big Book dalam Mengembangkan Kemampuan Berbahasa Reseptif Anak Usia Dini pada tahun 2020 (Fitriani, D. et al., 2019), Pengembangan Kemampuan Bahasa Reseptif Anak Usia Dini pada tahun 2019 (Alam \& Lestari, 2019), A Child Language Acquisition in Indonesian and English Language: A Longitudinal Case Study tahun 2019 (Fitriani, S., 2019), Reciprocal Factors of Language Development in Indonesian Children From Age 3 to 5 Years Old tahun 2019 (Wahyuni, 2019). Penelitian-penelitian terdahulu menjelaskan pentingnya pengembangan bahasa reseptif pada usia emas untuk menjadi dasar kemampuan berbahasa. Beberapa diantara penelitian terdahulu meneliti media yang digunakan untuk meningkatkan bahasa reseptif pada anak usia dini dan beberapa yang lain meneliti mengenai faktor yang mempengaruhi bahasa reseptif pada anak usia dini. Berikut langkah-langkah yang digunakan dalam penelitian ini.

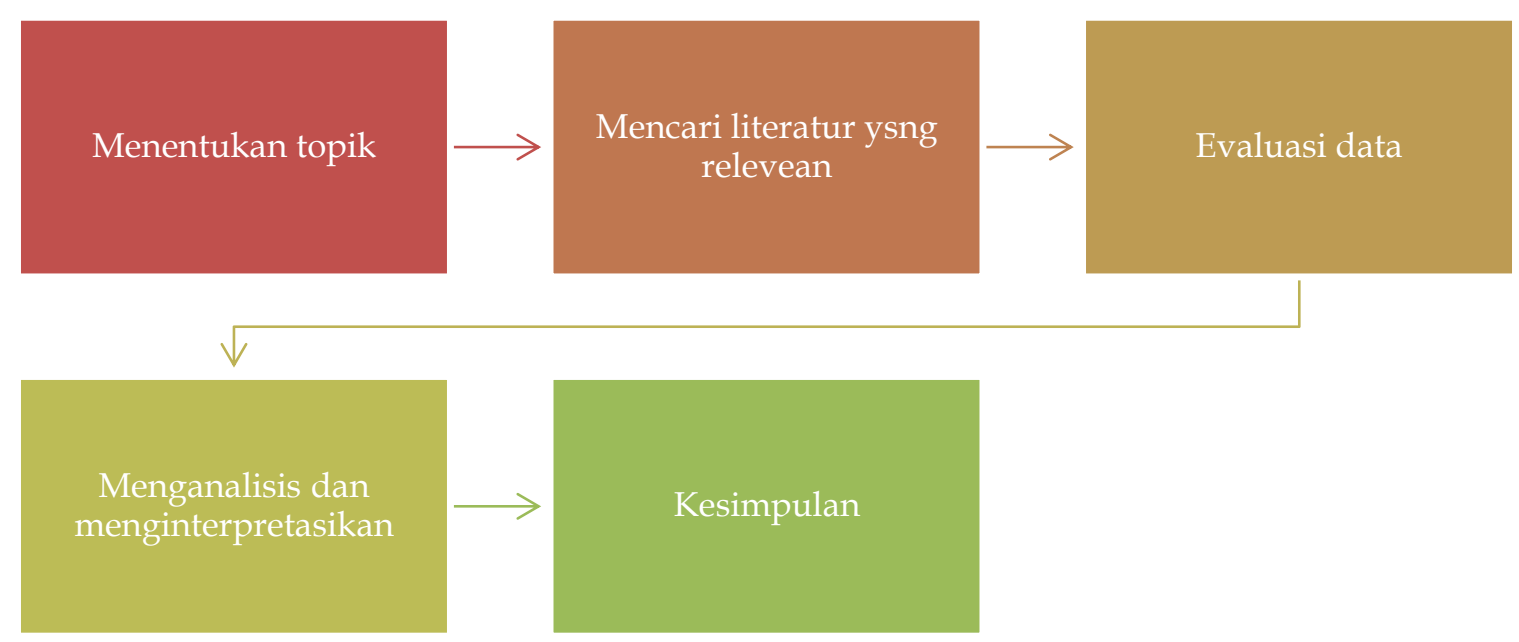

Gambar 1. Langkah Penelitian 


\section{HASIL DAN PEMBAHASAN}

\section{Bahasa}

Bahasa adalah alat komunikasi dengan menggunakan tanda, symbol, atau suara berpola tetap dan memiliki kaidah yang dikeluarkan dari alat ujar atau alat indera pada manusia. Sebagai alat komunikasi bahasa terdiri dalam bentuk satuan seperti kata, kelompok kata, klausa, dan kalimat (Arnianti, 2019: 140; Rosalina, 2014: 20). Ahli linguistic memperdebatkan pendapat bahwa bahasa hanya dimiliki manusia, meskipun terdapat pendapat mengenai bahasa yang juga dimiliki oleh hewan. Namun, bahasa hewan merupakan berupa bunyi dengan isyarat dan diasumsikan merupakan bahasa tersendiri (Coe et al., 1992;Fridani, Lara; Dhieni, 2014: 4). Santrock menjelaskan bahawa bahasa suatu bentuk komunikasi yang merupakan system symbol (Rosalina, 2014: 28). Bahasa digunakan memiliki system sendiri yang disebut tata bahasa, seperti halnya penggunaan bahasa Indonesia memiliki tata bahasa yang berbeda dengan tata bahsa Inggris. Menurut kamus besar bahasa Indonesia, bahasa merupakan system lambing bunyi yang arbitrer, yang digunakan masyarakat untuk bekerja sama, berinteraksi, dan mengidentifikasikan diri (KBBI, 2020). Sehingga, bahasa merupakan hal pembeda karena memiliki tata bahasa, bersifat produktif, terdapat konteks peristiwa, dan bahasa manusia berupa symbol yang digunakan untuk berkomunikasi satu dengan yang lain dengan setiap bunyi atau symbol.

Simbol dalam bahasa dilihat dari adanya daya cipta dan system yang meliputi fonologi, morfologi, sintaksis, semantic, pragmatic. forfolgi adalah system bunyi dari bahasa, termasuk bunyi yang digunakan atau system bunyi-bunyian dalam bahasa. Morfologi adalah satuan makna yang terlibat dalam pembentukan kata atau pengombinasian morfem. Sintaksis terkait dengan penyususnan kalimat yang tepat sehingga membentuk ungkapan dan kalimat yang sesuai seperti tata bahasa. Semantic adalah makana dari kata dan kalimat. Pragmatic adalah penggunaan bahasa yang tepat sesuai dengan aturan penggunaan atau maksud dalam berbagai konteks.

Konteks bahasa yang dimaksud yakni konteks social yang meliputi konteks situasi dan konteks kultural (Wiratno, Tri, 2014: 14). Konteks situasi merupakan penggunaan bahasa pada lingkungan langsung, dan konteks kultural adalah system nilai dan norma yang merepresentasikan kebudayaan atau kepercayaan tertentu. Terdapat 5 karatker bahasa menurut para ahli, yakni a) Sistematis, bahwa bahasa bersifat teratur dan memiliki pola-pola yang relatif konsisten; b) Arbitier, bahwa bahasa terdiri dari hubungan-hubungan yang arbitrari antara berbagai macam suara dan visual yang jelas, objek, maupun gagasan; c) Fleksibel, bahwa bahasa dapat berubah sesuai dengan perkembangan zaman; d) Beragam, bahwa dalam hal pengucapan, bahasa memiliki berbagai variasi dialek atau cara; e) Kompleks, bahwa kemampuan berpikir dan bernalar dipengaruhi oleh kemampuan menggunakan bahasa yang menjelaskan berbagai konsep, ide, maupun hubungan-hubungan yang dapat dimanipulasikan saat berpikir dan bernalar.

Bahasa alat komunikasi bagi semua orang, tidak hanya digunakan oleh individu dewasa namun juga digunakan untuk anak usia dini. Bagi anak usia dini bahasa memiliki tujuh fungsi, yaitu : a) fungsi instrumental, seperti menggunakan bahasa untuk pemenuhan kebutuhan primer seperti makan, ingin buang air kecil, atau merasa sakit maka anak akan mengucapakan sesuatu, diawali pada amasa bayi seperti menggunakan tangisan. Hal tersebut membuktikan bahawa fungsi bahasa instrumental yakni memudahkan orang lain mengerti; b) fungsi regulative, bahasa digunakan anak karena ada pengaruh dari lingkungan dan control perilaku orang dewasa; c) fungsi heuristic, bahasa untuk memperoleh ilmu pengetahuan dan mempelajari lingkungan; d) fungsi interasional, berfungsi menjalin komunikasi sehingga membentuk interaksi social; e) fungsi personal, untuk mengungkapkan atau mengekspresikan perasaan, emosi, ide, pendapat, dan pemahaman; d) fungsi imajinatif, bahasa digunakan untuk menceritakan cerita imajinatif biasanya pada anak-anak saat bermain peran; dan e) fungsi representasi, yaitu untuk menyamoaikan fakta dan pengetahuan. Pada 
anak-anak fungsi ini terlihat saat anak bercerita mengenai pengalaman atau kegiatan yang ia telah lakukan.

Fungsi bahasa bagi anak terjadi secara bertahap sesuai dengn usia perkembangannya. Pada saat bayi, bahasa memiliki 3 fungsi yakni fungsi instrumental, regulasi, dan interaksional. Saat anak berusia 18 bulan, anak mulai menggunakan ketujuh fungsi bahasa tersebut, dan seiring bertambahnya usia anak akan menggunakannya dengan sempurna (Fridani, Lara; Dhieni, 2014). Menurut Vygotsky bahasa membantu kemampuan berpikir karena kedua berkembang bersama contohnya anak yang telah menguasai bahasa maka daya nalarnya pun sudah cukup utnuk menyampaikan ide dan menerima pembelajaran, perintah atau pengetahuan-pengetahuan baru yang diberikan dari stimulus-stimulus yang ada di lingkungannya karena anak telah memiliki pemahaman bahasa (Rosalina, 2014: 26). Bahasa sebagai alat social karena menjadi jembatan komunikasi sehingga tercipta kehidupan social. Melalui bahasa anak mampu mengembangkan kemampuan sosialnya karena dengan penguasaan bahasa yang baik anak mampu menyampaikan dan mengekspresikan pikirannya sehingga menciptakan hubungan social .

Bahasa merupakan kesepakatan atau suatu perjanjian antar masyarakat dan bersifat alamiah yang interaktif. Bahasa merupakan cara berkomunikasi, pikiran, dana perasaan dalam bentuk symbol, lisan, tulisan, isyarat, lukisan, bilangan, dan apapun yang mampu menyampaikan pesan sehingga menciptakan komunikasi dan mengekspresikan ide, perasaan serta pengalaman. Bahasa tidak hanya disimbolkan dengan bahasa verbal, bisa jadi individu yang tidak mengungkapkan dengan verbal menggunakan bahasa menggunakan bahasa lain, seperti bahasa tubuh, atau symbol lain yang non linguistic. Hal tersebut memerlukan jembatan penghubung yakni pemahaman atau reseptor berupa penginderaan lain untuk memahami suatu bahasa. Seperti indera pendengaran sebagai reseptor suara yang menangkap bunyi sehingga individu dapat mengartikan bahasa yang sedang digunakan lawan komunikasi. Empat aspek bahasa menurut Khoiriyah (Karlina, 2018: 2), yakni menyimak, berbicara, membaca dan menulis. Bahasa selalu dianggap sebagai teks yang mengekspresikan makna secara kontekstual (Wiratno, Tri, 2014: 9). Yang sering disalah artikan bahwa kemampuan bahasa sama dengan kemampuan berbicara, sedangkan bahasa terkait dengan dua sifat yakni reseptif dan ekspresif.

\section{Bahasa Reseptif Anak Usia 3-6 Tahun}

Perkembangan bahasa reseptif merupakan proses yang kompleks. Bahasa reseptif yakni kemampuan awal dalam penguasaan bahasa yakni mengerti dan dimengerti, menerima dan mengkode atau menafsirkan bahasa dengan menyimak symbol visual maupun verbal, seperti kegiatan membaca dan menyimak yang merupakan kemampuan pemahaman. Kemampuan dalam saling mengenal dan merespon seseorang terhadap suatu kejadian juga merupakan bahasa reseptif (Aulina, 2012; Indah, 2011;McIntyre et al., 2017). Sejalan dengan Peraturan Menteri Pendidikan dan Kebudayaan RI No. 137 tahun 2014 mengenai bahasa reseptif yakni mencakup kemampuan memahami cerita, perintah, aturan, menyenangi dan menghargai bacaan. Reseptif secara harfiah bahasa Indonesia memiliki arti menerima, terbuka, menerima pendapat (KBBI, 2020). Sehingga, bahasa reseptif adalah kemampuan menerima dan memahami symbol bahasa, baik secara verbal maupun non verbal. Bahasa reseptif dan ekspresif memiliki kecepatan yang berbeda, seperti menulis memerlukan waktu yang lama dibanding kemampuan bahasa reseptif. Contoh bahasa reseptif yakni mendengarkan dan membaca suatu informasi merupakan kemampuan perkembangan yang lebih dulu dimiliki manusia.

Sebelum anak mulai memproduksi bahasa, anak belajar mengenali suara manusia. Kemudian anak mulai menyegmentasikan dan mengasosiasikan makna dari suara yang didengar dari lingkungan anak. Keterampilan pemahaman dan menyusun dasar bersosialisasi di lingkungan dan membantu kegiatan belajar pada anak dan mempengaruhi kemampuan pada aspek perkembangan lain seperti potensi perkembangan anak berupa kognitif, sosial 
dan emosional (McIntyre et al., 2017: 1). Bahasa reseptif juga terdapat pada Peraturan Menteri Pendidikan dan Kebudayaan Republik Indonesia No. 137 Tahun 2014 tentang Standar Nasional Pendidikan Anak Usia Dini, Tingkat Pencapaian Perkembangan Bahasa pada setiap tingkat usia (Permendikbud, 2014). Standar ini bukan merupakan standar yang mutlak bagi perkembangan anak namun dapat menjadi acuan apabila menilai sejauh mana tingkat perkembangan dan melihat apakah terjadi suatu keterlambatan dalam perkembangan anak berdasarkan tingkatan usia perkembangan. Tingkatan usia yang terdapat dalam standar pencapaian anak usia dini ini juga mendefinisikan bahwa di Indonesia anak usia dini merupakan anak yang berada pada usia 0-6 tahun. Hal ini berbeda pendapat mengenai usia pada anak usia dini menurut National Association for the Education of Young Children (NAEYC) yakni anak usia dini merupakan anak yang berusia 0-8 tahun. Sama dengan peraturan Menteri mengenai standar perkembangan berdasarkan usia perkembangan, NAEYC juga membaginya ke dalam kelompok-kelompok usia. Penelitian ini memfokuskan pada kemampuan bahasa reseptif anak usia dini pada usia sekolah awal atau usia 3-6 tahun. Usia tersebut merupakan masa dimana mayoritas perkembangan bahasa anak terjadi (McIntyre et al., 2017: 1). Menurut Carol E. Catron (dalam Christianti, 2015), pada usia 3 tahun, anak mulai memahami tata bahasa atau struktur kata yang menjadi kalimat sehingga pada usia 4 tahun anak mampu berbicara lebih bermakna. Hal tersebut diartikan bahwa bahasa reseptif yang dimiliki anak akan sejalan dengan kemampuan bahasa ekspresifnya.

Pendidikan di Indonesia memiliki standar tingkat pencapaian perkembangan bahasa reseptif yang dibagi berdasarkan kelompok usia yang terdapat dalam Peraturan Menteri Pendidikan dan Kebudayaan no.137 (Permendikbud, 2014), tabel 1 adalah standar tingkat pencapaian bahasa reseptif pada anak usia 3-6 tahun :

Tabel 1. Standar tingkat pencapaian bahasa reseptif pada anak usia 3-6 tahun

\begin{tabular}{ll}
\hline & Standar Tingkat Perkembangan Bahasa Reseptif Permendikbud \\
\hline Usia 3-4 tahun & 1. Bermain peran seolah sedang membaca buku dengan kata-katanya sendiri. \\
& 2. Memahami dua perintah yang diberikan bersamaan. \\
& 1. Menyimak perkataan orang lain (bahasa). \\
& 2. Mengerti dua perintah secara bersamaan. \\
& 3. Memahami cerita yang dibacakan. \\
& 4. Mengenal perbendaharaan kata sifat. \\
5sia 5-6 tahun & 1. Mendengar dan membedakan bunyi dalam bahasa \\
& 2. Mengulang kalimat yang kompleks. \\
& 3. Memahami aturan permainan. \\
4. Senang dan menghargai bacaan.
\end{tabular}

Melalui penelitian Wahyuni (2019:2), ia menggunakan standar perkembangan bahasa reseptif pada anak usia 3-5 tahun diadaptasi dari "American-Speech-Language Hearing Association on How Does Your Child Hear and Talk?" yang dibagi berdasarkan usia perkembangannya untuk melihat faktor yang dominan dalam memegaruhi kemampuan bahasa reseptif pada anak usia dini. Tabel 2 adalah standar perkembangan bahasa reseptif.

Bahasa diperkenalkan sedini mungkin untuk memperoleh keterampilan bahasa yang baik. Untuk itu perlu stimulan-stimulan dari faktor-faktor pengembangan bahasa pada anak usia dini. Stimulus-stimulus bahasa ini tidak hanya dapat diberikan kepada anak ketika anak sudah memasuki sekolah, namun jauh sebelum itu anak dapat belajar bahasa melalui lingkungan terdekatnya terleih dahulu. Lingkungan terdekat anak seperti keluarga, teman sejawat, media elektronik, media non eletronik. Lingkungan yang baik dalam memberikan stimulus bahasa yang kemudian menjadikannya sebagai budaya literasi pada anak usia dini. Di Indonesia budaya literasi rendah, kebiasaan membaca sedak dini merupakan faktor yang menyebabkan budaya literasi di Indonesia rendah (Permatasari, 2015: 147). Sedangkan 
membudayakan pembacaan buku atau story telling pada anak usia 3-6 merupakan faktor terkuat bagi negara-negara maju untuk menstimulus kemampuan bahasa reseptif pada anak serta aspek perkembangan lain (Kara \& Eveyik-Aydın, 2019: 135). Melalui membacakan cerita pada anak dapat menunjukkan kemampuan bahasa reseptif anak, seperti anak mampu menyimak dengan tenang, menjawab pertanyaan terkait cerita atau menceritakan kembali, mampu melakukan perintah yang sesuai diucapkan orang lain (Marcela et al., 2020: 34). Namun, di Indonesia hal ini tidak menjadi budaya, berbeda dengan budaya luar negeri yang membacakan dongeng pada anak sebelum tidur merupakan suatu hal yang membudaya.

Tabel 2. Standar perkembangan bahasa reseptif

\begin{tabular}{ll}
\hline & \multicolumn{1}{c}{$\begin{array}{c}\text { Standar Perkembangan Bahasa Reseptif } \\
\text { "American-Speech-Language Hearing Association" }\end{array}$} \\
\hline Usia 3 tahun & $\begin{array}{l}\text { 1. Memahami antonym (seperti atas-bawah, besar-kecil). } \\
\text { 2. Mampu memahami perintah (contoh anak mampu meletakkan buku di atas } \\
\text { meja sesuai perintah). } \\
\end{array}$ \\
& 3. Tertarik dengan cerita dan mendengarkan cerita dengan jangka waktu yang \\
Usia 3-4 tahun & 1. Dapat lama. \\
& 2. Mampu mendengarkan suara tv/radio dengan volume yang keras \\
& 3. Dapat menjawab pertanyaan dengan kata tanya (seperti apa, mengapa, \\
& bagaimana, kapan). \\
Usia 4-5 tahun & 1. Memperhatikan cerita pendek dan mampu menjawab pertanyaan tentang \\
& 2. Mereka \\
& 2. Mendengar dan memahami perkatan di rumah dan di sekolah.
\end{tabular}

Anak usia dini di Indonesia lebih cenderung menghabiskan waktunya di depan layer TV maupun gadget. Data BPS menunjukkan bahwa penduduk di Indonesia belum menjadikan membaca sebagai cara mencari informasi. Dari total penduduk Indonesia membaca hanya naik 0,2\% dari tahun 1993 menjadi 23,5\% dibanding dengan televisi dan gadget yakni 85,9\% (Rachmawati et al., 2019: 2). Sedangkan hasil penelitian dan studi bahasa, read aloud atau membacakan buku pada anak masih menjadi faktor atau stimulus tertinggi karena dapat menciptakan interaksi orangtua dan anak yang berkualitas (Marcela et al., 2020: 35; Wahyuni, 2019; Nuryanto, 2017: 43). Pihak yang mendukung perkembangan bahasa reseptif pada anak usia dini yakni orang tua, wali, anggota keluarga, pendidik, ahli, teman sejawat, lingkungan, dan media atau teknologi (Wahyuni, 2017: 2; McIntyre et al., 2017: 1). Faktor dengan prosentase dari yang tertinggi-rendah yang mempengaruhi perkembangan bahasa reseptif anak adalah kualitas interaksi, pengetahuan orangtua, lingkungan, social ekonomi, dan masalah bawaan sejak lahir (Wahyuni, 2019). Orangtua menjadi faktor yang dominan dalam memahami tentang bagaimana menciptakan komunikasi dengan anak serta memengaruhi perkembangan bahasa anak usia 3-6 tahun. sehingga orangtua harus mampu tidak hanya mendidik namun menstimulasi perkembangan bahasa anak dan memperhatikan tahapan yang dapat dilakukan dengan waktu berinteraksi yang berkualitas.

Anak usia dini memulai kemampuan bahasa dengan mengenali lingkungan dengan mengerti mimic dan suara, dan merespon dengan melakukan komunikasi preverbal seperti tangisan (Indah, 2011: 4). Contoh lainnya ketika anak mengenal kebiasaan guru, setiap guru mengambil peralatan music anak sudah mengetahui bahwa kelas music akan segera dimulai. Hal tersebut membuktikan bahwa anak telah memiliki dasar bahasa reseptif yakni memahami bahasa tubuh dan suara. Semakin matang kemampuan kemampuan bahasa reseptif anak maka kesiapan anak dalam berkomunikasipun semakin baik dan dapat menjadi tanda bahwa anak siap untuk belajar di sekolah. Anak usia 3-6 tahun perlu menggunakan bahasa secara aktif di seluruh kegiatan belajar mengajar untuk membangun pengetahuan baru (McIntyre et al., 2017: 2). 


\section{SIMPULAN}

Melalui hasil penelitian ini dapat disimpulkan bahwa bahasa reseptif adalah kemampuan dalam penguasaan bahasa yakni mengerti dan dimengerti, menerima dan mengkode atau menafsirkan bahasa dengan menyimak symbol visual maupun verbal. Bahasa reseptif anak usia 3-6 tahun yakni anak mulai menunjukkan bahwa ia telah memahami tata bahasa dalam percakapan, anak mulai tertarik dengan bacan atau cerita, anak mulai memahami hubungan bunyi dan kata. Faktor dominan dalam memegaruhi kemampuan bahasa reseptif anak usia 3-6 tahun adalah komunikasi yang terjadi saat interaksi atau berkegiatan bersama orangtua, seperti membacakan dongeng atau bercerita.

\section{UCAPAN TERIMA KASIH}

Atas rahmat Allah SWT penulis dapat menyelesaikan penelitian ini. Terimakasih kepada dosen yang selalu memberikan bimbingan dan ilmunya. Semoga hasil penelitian ini dapat bermanfaat bagi pembaca.

\section{DAFTAR PUSTAKA}

Alam, S. K., \& Lestari, R. H. (2019). Pengembangan Kemampuan Bahasa Reseptif Anak Usia Dini dalam Memperkenalkan Bahasa Inggris melalui Flash Card. Jurnal Obsesi : Jurnal Pendidikan Anak Usia Dini, 4(1), 284. https:/ / doi.org/10.31004/obsesi.v4i1.301

Amer Hasan, Marilou Hyson, M. C. C. (2013). Early Childhood Education and Development in Poor Villages of Indonesia. Washington: The world bank. https:// doi.org/http:/ / dx.doi.org/10.1596/978-0-8213-9836-4

Arnianti. (2019). Teori Perkembangan Bahasa. Pendidikan dan Ilmu Sosial, 1(1), 139-152. https://doi.org/doi.org/10.36088/pensa.v1i1.352

Aulina, C. N. (2012). Pengaruh Permainan dan Penguasaan Kosakata Terhadap Kemampuan Membaca Permulaan Anak Usia 5-6 Tahun. PEDAGOGIA: Jurnal Pendidikan, 1(2), 131. https:/ / doi.org/10.21070/pedagogia.v1i2.36

Chairunnisa, C. (2018). Pemerolehan Bahasa Pada Bayi Dan Anak. Cakrawala Dini: Jurnal Pendidikan Anak Usia Dini, 9(2), 125-137. https://doi.org/10.17509/cd.v9i2.13964

Christianti, M. (2015). Membaca dan Menulis Permulaan Untuk Anak Usia Dini. Jurnal Pendidikan Anak, 2(2). https:// doi.org/10.21831/jpa.v2i2.3042

Clarissa, S. V., \& Zulfikar, T. (2018). Indonesian Word Awareness in Children First. english education journal, 9(2), 275-293. https:/ / doi.org/E-ISSN: 2085-3750

Coe, C. L., Savage, A., \& Bromley, L. J. (1992). Phylogenetic influences on hormone levels across the primate order. American Journal of Primatology. https:// doi.org/10.1002/ajp.1350280202

Creswell, J. W. (2007). Research Design: Qualitative, Quantitative and Mixed Method Aproaches. SAGE Publications. https://doi.org/10.4135/9781849208956

Ersan, C. (2020). Early Language Development and Child Aggression. World Journal of Education, 10(1), 1. https://doi.org/10.5430/wje.v10n1p1

Fitriani, D., Fajriah, H., \& Rahmita, W. (2019). Media Belajar Big Book dalam Mengembangkan Kemampuan Berbahasa Reseptif Anak Usia Dini. Jurnal Obsesi : Jurnal Pendidikan Anak Usia Dini, 4(1), 247. https:/ / doi.org/10.31004/obsesi.v4i1.197

Fitriani, S. (2019). A Child Language Acquisition in Indonesian and English Language: A Longitudinal case study. Register Journal, 12(2), 126-156. https:/ / doi.org/10.18326/rgt.v12i2.126-156

Fridani, Lara; Dhieni, N. (2014). Hakikat Perkembangan Bahasa Anak. Metode pengembangan bahasa.

Indah, R. N. (2011). Proses Pemerolehan Bahasa: Dari Kemampuan Hingga Kekurangmampuan Berbahasa. LiNGUA: Jurnal Ilmu Bahasa dan Sastra, 3(1), 1-17. https:// doi.org/10.18860/ling.v3i1.570 
DOI: 10.31004/obsesi.v5i2.1015

Kara, K., \& Eveyik-Aydın, E. (2019). Effects of TPRS on Very Young Learners' Vocabulary Acquisition. Advances in Language and Literary Studies, 10(1), 135. https://doi.org/10.7575/aiac.alls.v.10n.1p.135

Karlina, D. N. (2018). Meningkatkan Kemampuan Berbicara Anak Tk B Usia 5-6 Tahun Melalui Digital Storytelling Di Tk Apple Kids Salatiga Semester I Tahun Ajaran 2017/ 2018. JPUD - Jurnal Pendidikan Usia Dini, 12(1), 1-11. https:/ / doi.org/10.21009//jpud.121.01

KBBI. (2020). Kamus Besar Bahasa Indonesia (KBBI) Kamus versi online/daring.

Kid Sense Child Development. (2013). Receptive Language (Understanding Words and Language). Occupational Therapy/Speech Pathology, 1-6.

Marcela, R. A., Rozie, F., Guru, P., Anak, P., Dini, U., Keguruan, F., ... Rozie, F. (2020). Penerapan Metode Bercerita dalam Optimalisasi Bahasa Reseptif Anak Usia 5-5 Tahun di TK Negeri 02 Tenggarong. Jurnal Lentera Anak, 1(1), 27-38.

McIntyre, L. J., Hellsten, L. ann M., Bidonde, J., Boden, C., \& Doi, C. (2017). Receptive and expressive English language assessments used for young children: A scoping review protocol. Systematic Reviews, 6(1), 1-7. https:/ / doi.org/10.1186/s13643-017-0471-1

Nuryanto, S. (2017). Penggunaan Metode Read Aloud untuk Mendongeng pada Anak Usia Dini. Jurnal Audi, 1(1).

Papalia, D. E. (2015). Human Development (Psikologi Perkembangan). In Cetakan ke-1.

Permatasari, A. (2015). Membangun Kualitas Bangsa dengan Budaya Literasi. In Seminar Nasional Bulan Bahasa UNIB (hal. 146-156).

Permendikbud. (2014). Standar Nasional Penilian PAUD No. 137. Menteri Kesehatan Republik Indonesia Peraturan Menteri Kesehatan Republik Indonesia.

Rachmawati, T. S., Winoto, Y., \& Rohman, A. S. (2019). Study on Mapping of Information Literature Culture in South Coastal Communities West Java Province. Record and Library Journal, 4(1), 1. https:/ / doi.org/10.20473/rlj.v4-i1.2018.1-7

Rhoades, E. A. (2011). Commentary: Literature reviews. Volta Review, 111(1), 61-71. https://doi.org/10.17955/tvr.111.1.677

Rosalina, A. (2014). Peningkatan Kemampuan Bahasa Anak Usia Dini Melalui Kegiatan Bermain. Psycho Idea, 1, 19-35. https:/ / doi.org/10.30595/ psychoidea.v9i1.239

Rusniah, R. (2017). Meningkatkan Perkembangan Bahasa Indonesia Anak Usia Dini Melalui Penggunaan Metode Bercerita Pada Kelompok a Di Tk Malahayati Neuhen Tahun Pelajaran 2015/2016. JURNAL EDUKASI: Jurnal Bimbingan Konseling, 3(1), 114. https://doi.org/10.22373/je.v3i1.1445

Susanto, H. (2016). Membangun Budaya Literasi Dalam Pembelajaran Bahasa Indonesia Menghadapi Era MEA. JP-BSI (Jurnal Pendidikan Bahasa dan Sastra Indonesia). https:// doi.org/10.26737/jp-bsi.v1i1.70

Wahyuni, I. (2019). Reciprocal Factors of Language Development In Indonesian Children. In Konferensi Linguistik Tahunan Atma Jaya (hal. 1-6).

Wiratno, Tri, R. S. (2014). No Title. In Modul Bahasa (hal. 1-19).

Woodrow, L., \& Woodrow, L. (2019). Writing the Literature Review. In Doing a Master's Dissertation in TESOL and Applied Linguistics. https:/ / doi.org/10.4324/978042950406810 